\title{
Molecular Beacon DNA Probes with Fluorescein Bifluorophore
}

\author{
V. A. Brylev ${ }^{a,}$, I. L. Lysenko ${ }^{b}$, E. A. Kokin ${ }^{a}$, Y. V. Martynenko-Makaev ${ }^{b}$, D. Y. Ryazantsev ${ }^{a}$, \\ V. V. Shmanai ${ }^{b}$, and V. A. Korshun ${ }^{a, c, d}$ \\ ${ }^{a}$ Shemyakin-Ovchinnikov Institute of Bioorganic Chemistry, Moscow, 117997 Russia \\ ${ }^{b}$ Institute of Physical Organic Chemistry of NAS Belarus, Minsk, 220072 Belarus \\ ${ }^{c}$ Department of Biology and Biotechnology, National Research University Higher School of Economics, Moscow, 117312 Russia \\ ${ }^{d}$ Gause Institute of New Antibiotics, Moscow, 119021 Russia \\ Received October 19, 2020; revised October 26, 2020; accepted October 31, 2020
}

\begin{abstract}
An azido-derivative of a fluorescein bifluorophore was obtained and used for the synthesis of "molecular beacon"-type oligonucleotide fluorogenic probes for RT-PCR. Eight probe variants were synthesized based on an optimized sequence: with one or two quencher residues at the 3 '-end, with a single or bifluorophore fluorescein label attached to 5 '-end using modifying phosphoramidites (short linker) or "click reaction" (long linker). Comparison of probes in RT-PCR showed that probes with a doubled quencher (single fluorescein on a short linker) and doubled dye on a short linker (single dye) are somewhat superior in sensitivity to a standard probe (single quencher, single dye on a short linker) by the value of $\Delta \mathrm{C}_{\mathrm{t}}=1-2$.
\end{abstract}

Keywords: fluorogenic DNA probes, 5-carboxyfluorescein, 3,5-diaminobenzoic acid, fluorescence quenching, real-time qPCR

DOI: $10.1134 / \mathrm{S} 1068162021030055$

\section{INTRODUCTION}

Fluorescent DNA probes, which are part of reagent kits for qualitative and quantitative detection of DNA and RNA, continue to be a powerful research and diagnostic tool [1-4]. One of the most important areas of application of such probes is the real-time polymerase chain reaction (RT-PCR) [5]. This method is used for express detection and semiquantitative (to the order of magnitude) analysis of genetic material; the most common uses of RT-PCR are molecular diagnostics of inherited diseases, genetically modified organisms, microbial and viral pathogens, for example, HIV [6] and SARS-CoV-2 [7]. In RT-PCR, various types of fluorogenic DNA probes are used, which are capable of increasing fluorescence when interacting with the accumulating PCR product; the fluorogenic effect is achieved as a result of the interaction of two dyes, one of which can be nonfluorescent (quencher) [5, 8]. For fluorogenic probes, the relationship between the type of dye and the structure of the probe is being studied [9], new dyes are being developed [10-12], and probes with two residues of a

Abbreviations: RT-PCR, real-time polymerase chain reaction; BHQ-1, 4'-(2-nitro-4-tolyldiazo)-2'-methoxy-5'-methylazobenzene-4-dialkylamine (fluorescence quencher); DMAP, 4dimethylaminopyridine;e EDC, 1-ethyl-3-(3-dimethylaminopropyl)carbodiimide; 5-FAM, 5-carboxyfluorescein amide; HOBt, 1-hydroxybenzotriazole.

${ }^{1}$ Corresponding author: phone: +7 (499) 724-67-15; e-mail: v.brylev@yandex.ru. fluorescent dye and/or a fluorescence quencher are being investigated [13-15]. The most popular dye for DNA probes is fluorescein, which is attached in the form of a carboxyl derivative at the amino group of a linker; such fluoresceinamide is abbreviated as FAM. Introduction of several fluorescein residues into the bioconjugate can lead to significant self-quenching of fluorescence [16]; on the other hand, attachment of fluoresceins with a rigid linker prevents self-quenching [17]. Earlier, we obtained FAM bifluorophores based on 3,5-diaminobenzoic acid [18, 19]. The purpose of this work was to study FAM-bifluorophore on various linkers compared to a single fluorescein label as part of fluorogenic molecular beacon oligonucleotide probes for RT-PCR.

\section{RESULTS AND DISCUSSION}

DNA probes of the molecular beacon type (Fig. 1) are an oligonucleotide carrying a fluorescent dye $(\mathrm{F})$ and a quencher (Q) at the $5^{\prime}-$ and $3^{\prime}$-ends, while the $5^{\prime}-$ and 3 '-end regions of the probe (5-7 nucleotides) are complementary. As a result, in an aqueous solution at room temperature, the probe exists predominantly in the form of a hairpin structure consisting of a stem and a loop, with the fluorophore and quencher located close to each other. The loop part of the molecular beacon is complementary to the target sequence (in RT-PCR, the PCR product), and, as a result of hybridization with it, the hairpin is destroyed, the dyes 


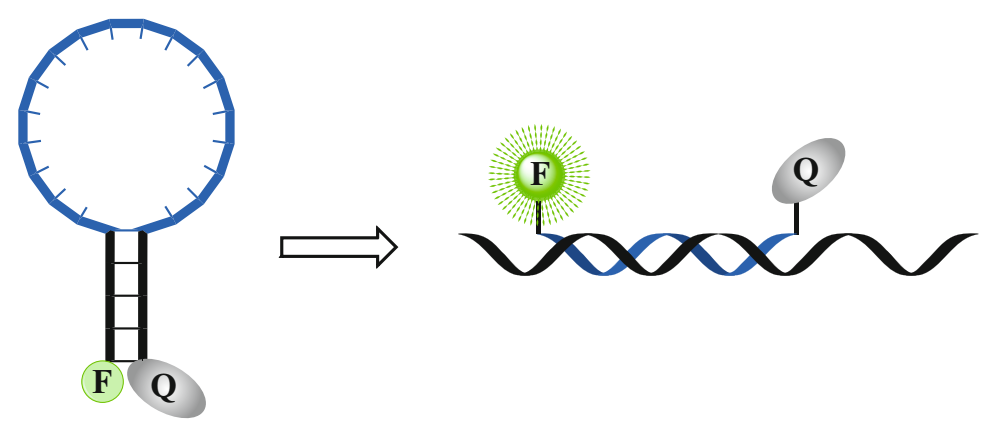

Fig. 1. The principle of operation of a fluorogenic molecular beacon DNA probe. F, fluorescent dye; Q, quencher.

are uncoupled, and fluorescence flares up (Fig. 1). Monitoring of the fluorescence intensity is carried out at each PCR cycle, recording as a result the dependence of the emission on the number of PCR cycles.

In this work, we used an optimized hairpin probe complementary to the region of the amplified fragment of the fungal translation factor $1 \alpha$ gene Fusarium avenaceum [14]. The nucleotide sequence of the probe, the structures of its chemical modifications, and approaches to the synthesis of 5-FAM-bifluorophore probes are shown in Fig. 2. Probes MB3 and MB4 (Table 1) were synthesized using phosphoramidite reagent (I) [18]. In this work, an azide reagent (V) based on 5-FAM-bifluorophore for labeling alkynemodified oligonucleotides using $\mathrm{Cu}(\mathrm{I})$-catalyzed cycloaddition reaction (click reaction) was obtained. The starting 3,5-bis(trifluoroacetylamino)benzoic acid (II) [20] was coupled with 3-azidopropylamine [21], followed by the deprotection of amino groups with ammonia. The resulting diamine (III) was acylated with pentafluorophenyl ether of dipivaloyl-protected 5-carboxyfluorescein (IV) [22]. Removal of pivaloyl protecting groups led to the formation of an azide derivative of 5-FAM-bifluorophore $(\mathbf{V})$. The latter was used to modify alkyne oligonucleotides in solution using a click reaction to afford probes MB7 and MB8 (Table 1). Single fluorescein probes were obtained using 5-FAM-phosphamidite [22] (MB1 and MB2) or click modification of alkyne oligonucleotides with a 5FAM-azide reagent [23] (MB5 and MB6) (Table 1). Terminal alkyne was introduced into oligonucleotides using a phosphamidite reagent [24]. The doubled quencher BHQ1 $\left(\mathrm{Q}_{2}\right)$ was introduced into oligonucleotides as described earlier [13]. All probe components are shown in Fig. 2. One or two BHQ1 (Q) quenchers are located at the 3'-end, while the 5'-end may have one or two fluorophores (5-FAM) attached using phosphamidites or the click-reaction with azide reagents.

When the hairpin probes are heated, the stem "melts" in the solution, leading to a flare-up of fluorescence. From the maximum of the first derivative of the function of the dependence of fluorescence intensity on temperature, one can determine the melting point of the probe (Table 1). It can be seen that the structure of the modification of the 5'-end region (linker and the number of 5-FAM residues) has almost no effect on the melting temperature of the probe. On the contrary, introduction of an additional quencher residue BHQ1 (Q) into the 3'-end region increases the melting point of the hairpin by $4-5^{\circ} \mathrm{C}$, which is consistent with previously published data [14]. It is difficult to infer any regularities in fluorescence enhancement of the probes during melting; it can only be noted that probes with short linkers give a greater increase of emission intensity (Table 1).

Under RT-PCR conditions, with the accumulation of the PCR product, an increasing portion of the probe forms a duplex with it, and upon heating, the probe-target complex melts. Therefore, the change in fluorescence upon melting of the duplex of the probe with the target was also studied (see Supplementary Information). When melting both the hairpin and the duplex with the target, probe MB2 with two quenchers showed the best melting cooperativity.

Then the probes were compared under RT-PCR conditions, and fluorescence detection in each cycle was carried out at two temperatures $\left(55\right.$ and $\left.64^{\circ} \mathrm{C}\right)$. Background fluorescence values relative to control probe $\mathbf{M B 1}$ ans the relative increase in fluorescence at the endpoint of the PCR in comparison with the initial fluorescence of the probe were obtained (Table 1). It can be seen that the additional quencher residue in all cases leads to some decrease in the initial (background) fluorescence (Table 1), and reduces the final flare-up of emission in the case of probes MB4 and MB6 (Fig. 3b).

To test the applicability of probes for quantitative detection of genetic material, a 10 -fold dilution series of the target was used. Probe MB1 allows target detection in the range of 50 zeptomol to 0.5 femtomol (Fig. 3a). The best sensitivity was demonstrated by probes MB2 (doubled quencher and single 5-FAM residue on a short linker) and $\mathbf{M B 3}$ (single quencher and FAM-bifluorophore on a short linker), they flared up about one cycle earlier than the standard probe MB1. The rest of the probes were inferior in sensitivity to MB1 (Fig. 3b). 


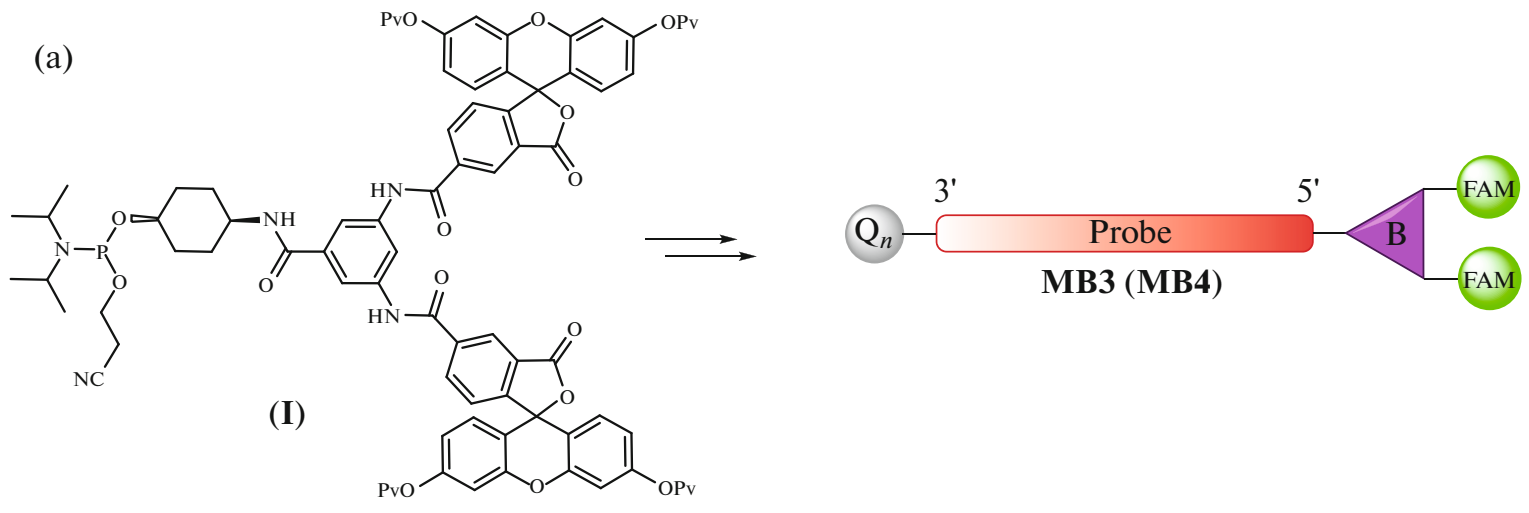

(b)

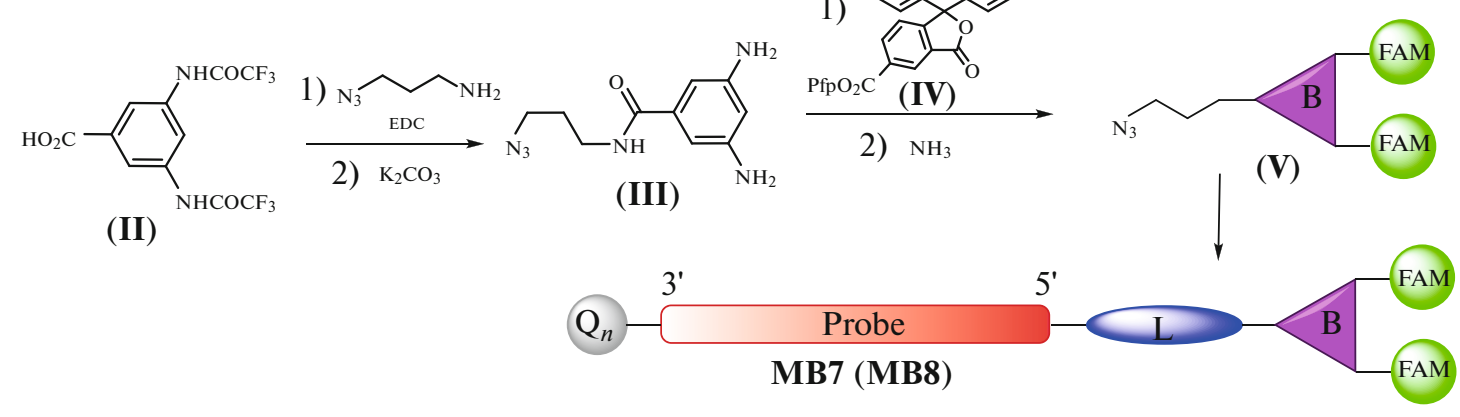

(c)

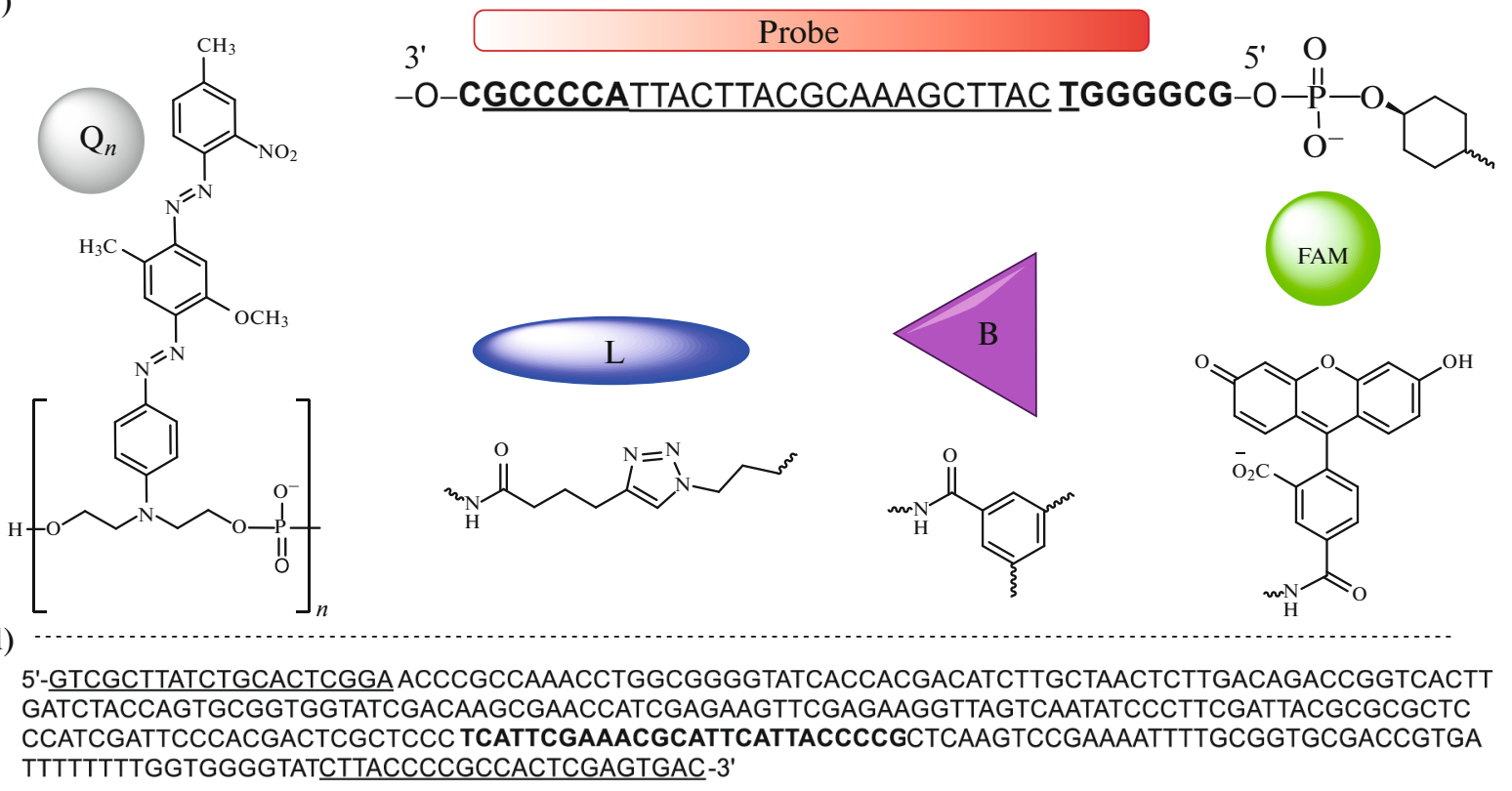

Fig. 2. Synthesis of oligonucleotide probes with 5-FAM-bifluorophore. Pv, pivaloyl; Pfp, pentafluorophenyl; FAM, 5-FAM fluorophore. (a) Probe synthesis schemes MB3 and MB4 using the amidophosphite method; (b) synthesis of the azido derivative (V) and probes MB7 and MB8; (c) the main components of the probe, Q, quencher; L, linker; B, the branching fragment based on 3,5-diaminobenzoic acid. The sequence of the probe complementary to the target is underlined; the fragments that form the stem of the hairpin are highlighted in bold; (d) detected sequence of a 290-bp fragment of the gene encoding translation elongation factor $1 \alpha$ of Fusarium avenaceum. Areas complementary to primers Fat65R and Fat65F are underlined; the section of the gene that binds to probes MB1-MB8 is highlighted in bold. 
MOLECULAR BEACON DNA PROBES

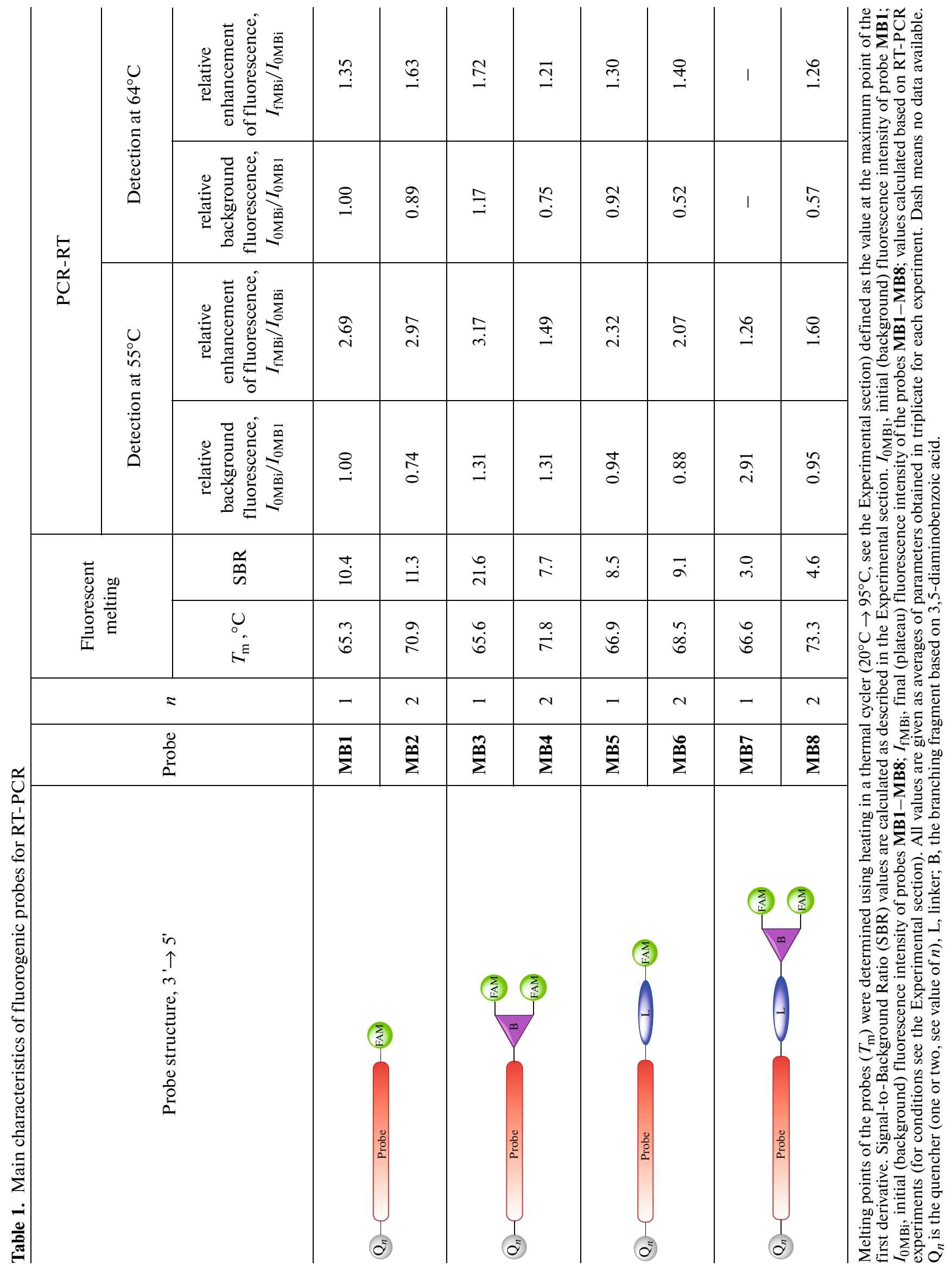



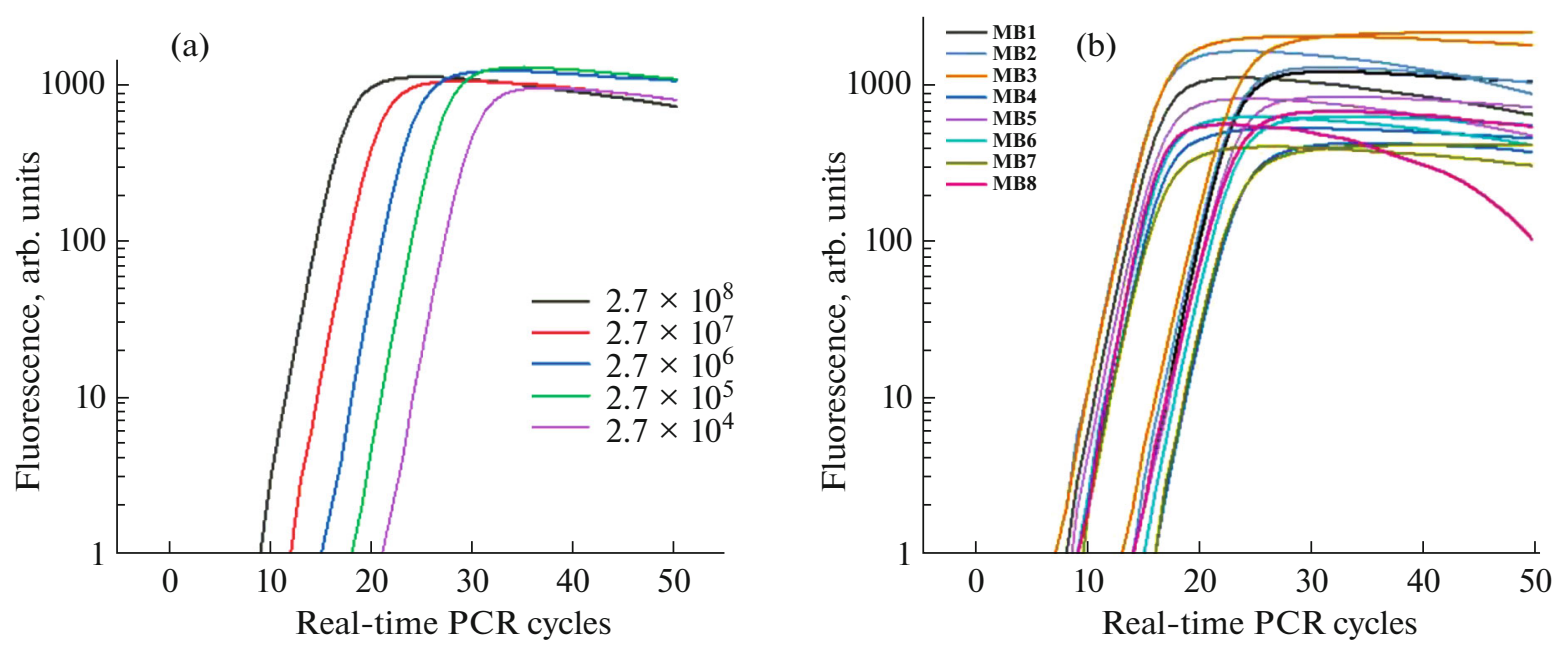

Fig. 3. Fluorescence enhancement profiles in quantitative RT-PCR; fluorescence detection at $55^{\circ} \mathrm{C}$. (a) Detection of different numbers of target molecules using probe MB1; (b) comparison of probes MB1-MB8 in RT-PCR with $2.7 \times 10^{7}$ (left) and $2.7 \times 10^{8}$ target molecules (right).

\section{EXPERIMENTAL}

All solvents and reagents were used without further purification. 3-Azidopropylamine [21], as well as compounds (II) and (IV) $[20,22]$ were synthesized as previously described. ${ }^{1} \mathrm{H}$ - and ${ }^{13} \mathrm{C}$-NMR spectra were obtained on a DRX-500 NMR spectrometer $(500 \mathrm{MHz}$; Bruker, Germany) with assignment of signals by the peaks of residual protons in DMSO- $d_{6}(2.50 \mathrm{ppm}$ for ${ }^{1} \mathrm{H}$ and $39.52 \mathrm{ppm}$ for ${ }^{13} \mathrm{C}$ ). J-Coupling constants are given in hertz $(\mathrm{Hz})$ for the corresponding multiplets. Thin layer chromatography was performed on TLC Silica gel $60 \mathrm{~F}_{254}$ aluminum plates (Merck, Germany).

3-Azidopropyl-3,5-bis (3',6'-dihydroxy-3-oxo-3Hspiro(isobenzo-furan-1,9'-xanthene)-5-ylcarboxyamido)benzoate (V). To acid solution (II) $(2.00 \mathrm{~g}$, $5.8 \mathrm{mmol})$ in DMF (15 mL), 3-azidopropylamine (700 mg, $6.9 \mathrm{mmol})$, EDC HCl $(1.67 \mathrm{~g}, 8.7 \mathrm{mmol})$, HOBt (1.18 g, $8.7 \mathrm{mmol}), \mathrm{Et}_{3} \mathrm{~N}(2.42 \mathrm{~mL}, 17.4 \mathrm{mmol})$ were added, and the reaction mixture was stirred for $12 \mathrm{~h}$ at room temperature under argon. Then the reaction mixture was diluted with AcOEt $(50 \mathrm{~mL})$, washed with water $(2 \times 30 \mathrm{~mL}), 10 \%$ citric acid solution $(3 \times$ $30 \mathrm{~mL}), 5 \% \mathrm{NaHCO}_{3}$ solution $(3 \times 30 \mathrm{~mL})$, saturated $\mathrm{NaCl}$ solution $(30 \mathrm{~mL})$, dried over $\mathrm{Na}_{2} \mathrm{SO}_{4}$, evaporated, and the residue was recrystallized from methylene chloride. 3,5-Di(trifluoroacetylamino)benzoic acid 3-azidopropylamide $(2.00 \mathrm{~g}, 81 \%)$ was obtained as a white powder. $R_{\mathrm{f}} 0.6$ (methanol-dichloromethane $5: 95(\mathrm{v} / \mathrm{v})$ ). Intermediate (II) ${ }^{1} \mathrm{H}$ NMR (DMSO- $d_{6}$ ), $\delta$, ppm: $11.54(\mathrm{~s}, 2 \mathrm{H}), 8.62(\mathrm{t}, J 5.6,1 \mathrm{H}), 8.24(\mathrm{t}, J 2.0$, $1 \mathrm{H}), 7.94(\mathrm{~d}, J 2.0,2 \mathrm{H}), 3.41(\mathrm{t}, J 6.8,2 \mathrm{H}), 1.78$ (quintet, $J 6.8,2 \mathrm{H})$.

To a solution of bistrifluoroacetamide (II) $(500 \mathrm{mg}$, $1.2 \mathrm{mmol})$ in methanol $(15 \mathrm{~mL}) \mathrm{K}_{2} \mathrm{CO}_{3}(842 \mathrm{mg}$, $6.1 \mathrm{mmol})$ and water $(4 \mathrm{~mL})$ were added, and the reac- tion mixture was stirred for $1.5 \mathrm{~h}$ while refluxing in an argon atmosphere. The reaction mixture was evaporated to dryness, evaporated with acetonitrile $(4 \times 20 \mathrm{~mL})$, dissolved in AcOEt $(30 \mathrm{~mL})$, dried over $\mathrm{Na}_{2} \mathrm{SO}_{4}$, and evaporated. Compound (III) was obtained as a yellowish oil, and further used without additional purification and characterization. $R_{\mathrm{f}} 0.32$ (methanoldichloromethane $1: 9(\mathrm{v} / \mathrm{v}))$.

Compound (III) was dissolved in DMF $(20 \mathrm{~mL})$, DMAP (428 mg, $3.5 \mathrm{mmol}), \mathrm{Et}_{3} \mathrm{~N}(488 \mu \mathrm{L}, 3.5 \mathrm{mmol})$, pentafluorophenyl ether of pivalate-protected carboxyfluorescein (IV) $(2.08 \mathrm{~g}, 2.9 \mathrm{mmol})$ were added, and the reaction mixture was stirred for 7 days at $50^{\circ} \mathrm{C}$ in an argon atmosphere. Then the reaction mixture was evaporated to dryness, diluted with AcOEt $(50 \mathrm{~mL})$, washed with water $(2 \times 30 \mathrm{~mL}), 10 \%$ citric acid $(2 \times 30 \mathrm{~mL}), 5 \% \mathrm{NaHCO}_{3}$ solution $(3 \times 30 \mathrm{~mL})$, and saturated $\mathrm{NaCl}$ solution $(30 \mathrm{~mL})$. The organic phase was dried over $\mathrm{Na}_{2} \mathrm{SO}_{4}$, evaporated, and the residue was chromatographed on silica gel in the dichloromethane/acetone system $(100: 0 \rightarrow 75: 25(\mathrm{v} / \mathrm{v}))$. The target fractions were combined, evaporated, the residue was dissolved in acetone $(15 \mathrm{~mL}), 25 \%$ aqueous ammonia solution $(2 \mathrm{~mL})$ was added, and the mixture was stirred for $1 \mathrm{~h}$ at room temperature. Excess ammonia and acetone were evaporated, the solution was diluted to $10 \mathrm{~mL}$ with water and adjusted with a $10 \%-\mathrm{HCl}$ solution to $\mathrm{pH} 2$; the precipitate was filtered and washed with water. It was recrystallized from a mixture of methanol and acetonitrile $(1: 9(\mathrm{v} / \mathrm{v}))$. Compound $(\mathbf{V})$ was obtained as a yellowish powder $(645 \mathrm{mg}, 58 \%) . R_{\mathrm{f}} 0.7$ (methanol-ethyl acetate $1: 3$ (v/v). ${ }^{1} \mathrm{H}-\mathrm{NMR}$ $\left(\mathrm{DMSO}-d_{6}\right), \delta$, ppm: $10.82(\mathrm{~s}, 2 \mathrm{H}), 8.69-8.65(\mathrm{~m}$, $2 \mathrm{H}), 8.62-8.57(\mathrm{~m}, 2 \mathrm{H}), 8.40(\mathrm{dd}, J 8.1,1.7,2 \mathrm{H}), 8.02$ $(\mathrm{d}, J 1.9,2 \mathrm{H}), 7.47(\mathrm{~d}, J 8.1,2 \mathrm{H}), 6.75(\mathrm{~d}, J 2.3,2 \mathrm{H})$, $6.64(\mathrm{~d}, J 8.7,4 \mathrm{H}), 6.62-6.58(\mathrm{~m}, 4 \mathrm{H}), 3.44(\mathrm{t}, J 6.8$, 
$2 \mathrm{H}$ ), 3.36 (qt, $J 6.4,2 \mathrm{H}$ ), 1.82 (quintet, $J 6.8,2 \mathrm{H}$ ). ${ }^{13} \mathrm{C}$ NMR (DMSO- $d_{6}$ ), $\delta \mathrm{C}, \mathrm{ppm}: 168.15,166.62$, 164.12, 159.91, 154.93, 151.97, 139.14, 136.42, 135.96, $135.23,129.22,126.61,124.55,124.11,115.56,115.46$, 112.90, 109.14, 102.40, 48.62, 36.83, 28.47.

Quantitative RT-PCR was carried out on a DTprime detecting amplifier (DNA technology, Russia) using a pair of primers Fat65R-Fat65F and plasmid pTZ-Fat containing a 290-bp fragment of the gene encoding translation elongation factor $1 \alpha$ of Fusarium avenaceum (Fig. $2 \mathrm{~d}$ ).

The reaction mixture $(35 \mu \mathrm{L})$ contained $83.75 \mathrm{mM}$ Tris- $\mathrm{HCl}, 20.75 \mathrm{mM}$ ammonium sulfate, $3.125 \mathrm{mM}$ magnesium chloride, $0.003 \%$ Tween-20, $0.003 \%$ NP$40,6.25 \%$ glycerol, $0.17 \mathrm{mM}$ of each dNTP, $0.36 \mu \mathrm{M}$ primers, $0.2 \mu \mathrm{M}$ of each probe from the set MB1MB8, 2.5 IU Taq polymerase and DNA template (plasmid pTZ-Fat, $2.7 \times 10^{4}-2.7 \times 10^{8}$ copies), $\mathrm{pH}$ 8.8. The experiments were repeated three times and analyzed by the geometric method $\left(\mathrm{C}_{\mathrm{q}}\right)$ using the Real-time PCR 7.9 software (DNA Technology, Russia). The background fluorescence of each sample well was taken into account. For quantitative detection of different matrix concentrations with an MB1 probe, a direct dependence of the number of cycles on the matrix content in the sample was observed, with $R^{2} \geq 0.99$. For quantitative PCR, a matrix solution with a predetermined concentration (measured spectrophotometrically at a wavelength of $260 \mathrm{~nm}$ ) was used. Aliquots were taken from this solution and samples with a known number of target molecules were obtained by subsequent dilution. RT-PCR program: $80^{\circ} \mathrm{C}$ for $60 \mathrm{~s}$; $94^{\circ} \mathrm{C}$ for $90 \mathrm{~s}(1 \mathrm{cycle})$; then $94^{\circ} \mathrm{C}$ for $30 \mathrm{~s}, 64^{\circ} \mathrm{C}$ for $15 \mathrm{~s}$ (5 cycles) and $94^{\circ} \mathrm{C}$ for $10 \mathrm{~s}, 64^{\circ} \mathrm{C}$ for $15 \mathrm{~s}$ ( 45 cycles) (fluorescence was recorded at 55 or $64^{\circ} \mathrm{C}$ using a detector in the FAM-channel).

Melting experiments on probes MB1-MB8 were carried out in three repetitions on the same device (FAM detection channel) with each probe from the row MB1-MB8 melted separately in a PCR buffer without dNTPs, primers, Taq polymerase and plasmid template. The concentration of each probe was $0.2 \mu \mathrm{M}$. The temperature was increased from 20 to $95^{\circ} \mathrm{C}$ in $0.5^{\circ} \mathrm{C}$ steps for $15 \mathrm{~s}$. For each step, the fluorescence level was measured. $\mathrm{MB}_{\mathrm{i}} /$ target duplexes were preliminarily annealed with a twofold excess of a short 26-mer complementary sequence and melted under the same conditions. Then, a graph of the dependence of the fluorescence intensity on temperature in the range of $20-95^{\circ} \mathrm{C}$ was constructed. Melting points were calculated as the maxima of the first derivative using the OriginPro 8 software. The signal-to-background ratio (SBR) for probes MB1-MB8 was calculated by the formula:

$$
\mathrm{SBR}=\left(I_{\mathrm{fMBi}}-I_{0}\right) /\left(I_{0 \mathrm{MBi}}-I_{0}\right),
$$

where $I_{0}$ is the fluorescent noise signal of a PCR sample containing all components, but without a probe;
$\mathrm{MB}_{\mathrm{i}}$, a test probe from the set MB1-MB8; $I_{0 \mathrm{MBi}}$, fluorescence $\mathrm{MB}_{\mathrm{i}}$ in the absence of a matrix; $I_{\mathrm{fMBi}}$, the fluorescence signal of prehybridized $\mathrm{MB}_{\mathrm{i}}$ with a short complementary 26-mer sequence 5'-CGGGGTAATGAATGCGTTTCGAATGA-3'. Measurements of the values of $I_{0}, I_{0 \mathrm{MBi}}, I_{\mathrm{fMBi}}$ were carried out at $20^{\circ} \mathrm{C}$ in a DTprime detecting amplifier (DNA Technology, Russia) with $0.2 \mu \mathrm{M} \mathrm{MB}$ and a twofold excess of the complementary oligonucleotide.

\section{CONCLUSIONS}

In this work, we investigated the efficiency of a FAM-bifluorophore based on 3,5-diaminobenzoic acid on various linkers compared to a single fluorescein label as part of fluorogenic molecular beacon oligonucleotide probes for RT-PCR. It has been shown that for such hairpin RT-PCR probes, it is preferable to attach fluorescein (both a single label and a bifluorophore) through a short linker using amidophosphite reagents. The highest sensitivity of the probe in RTPCR is achieved with the introduction of nonstandard modifications a doubled quencher or a doubled dye, but not both modifications simultaneously.

\section{FUNDING}

This work was supported by the Russian Foundation for Basic Research (grant 17-54-04111, V.A. Brylev) and the Belarusian Republican Foundation for Basic Research (grant M17PM-047, Yu.V. Martynenko-Makaev).

\section{COMPLIANCE WITH ETHICAL STANDARDS}

This article does not contain a description of experiments conducted by any of the authors of this article with the participation of humans or the use of animals as research objects.

\section{Conflict of Interests}

The authors declare they have no conflict of interest.

\section{SUPPLEMENTARY INFORMATION}

The online version contains supplementary material available at https://doi.org/10.1134/S1068162021030055.

\section{OPEN ACCESS}

This article is licensed under a Creative Commons Attribution 4.0 International License, which permits use, sharing, adaptation, distribution and reproduction in any medium or format, as long as you give appropriate credit to the original author(s) and the source, provide a link to the Creative Commons licence, and indicate if changes were made. The images or other third party material in this article are included in the article's Creative Commons licence, unless indicated otherwise in a credit line to the material. If 
material is not included in the article's Creative Commons licence and your intended use is not permitted by statutory regulation or exceeds the permitted use, you will need to obtain permission directly from the copyright holder. To view a copy of this licence, visit http://creativecommons.org/licenses/by/4.0/.

\section{REFERENCES}

1. Vilaivan, T., Beil. J. Org. Chem., 2018, vol. 14, pp. 253281. https://doi.org/10.3762/bjoc.14.17

2. Chen, J., Shi, C., Kang, X., Shen, X., Lao, X., and Zheng, H., Anal. Methods, 2020, vol. 12, pp. 884-893. https://doi.org/10.1039/c9ay02332a

3. Michel, B.Y., Dziuba, D., Benhida, R., Demchenko, A.P., and Burger, A., Front. Chem., 2020, vol. 8, p. 112. https://doi.org/10.3389/fchem.2020.00112

4. Quan, K., Yi, C., Yang, X., He, X., Huang, J., and Wang, K., Tr. Anal. Chem., 2020, vol. 124, p. 115784. https://doi.org/10.1016/j.trac.2019.115784

5. Navarro, E., Serrano-Heras, G., Castano, M.J., and Solera, J., Clin. Chim. Acta, 2015, vol. 439, pp. 231250. https://doi.org/10.1016/j.cca.2014.10.017

6. Farzan, V.M., Kvach, M.V., Aparin, I.O., Kireev, D.E., Prikazchikova, T.A., Ustinov, A.V., Shmanai, V.V., Shipulin, G.A., Korshun, V.A., and Zatsepin, T.S., Talanta, 2019, vol. 194, pp. 226-232. https://doi.org/10.1016/j.talanta.2018.10.043

7. Vogels, C.B.F., Brito, A.F., Wyllie, A.L., Fauver, J.R., Ott, I.M., Kalinich, C.C., Petrone, M.E., CasanovasMassana, A., Muenker, M.C., Moore, A.J., Klein, J., Lu, P., Lu-Culligan, A., Jiang, X., Kim, D.J., Kudo, E., Mao, T., Moriyama, M., Oh, J.E., Park, A., Silva, J., Song, E., Takahashi, T., Taura, M., Tokuyama, M., Venkataraman, A., Weizman, O.-E., Wong, P., Yang, Y., Cheemarla, N.R., White, E.B., Lapidus, S., Earnest, R., Geng, B., Vijayakumar, P., Odio, C., Fournier, J., Bermejo, S., Farhadian, S., Dela Cruz, C.S., Iwasaki, A., Ko, A.I., Landry, M.L., Foxman, E.F., and Grubaugh, N.D., Nat. Microbiol., 2020, vol. 5, pp. 12991305 . https://doi.org/10.1038/s41564-020-0761-6

8. Ranasinghe, R.T. and Brown, T., Chem. Commun., 2005, pp. 5487-5502.

https://doi.org/10.1039/b509522k

9. Farzan, V.M., Aparin, I.O., Veselova, O.A., Podkolzin, A.T., Shipulin, G.A., Korshun, V.A., and Zatsepin, T.S., Anal. Methods, 2016, vol. 8, pp. 5826-5831.

10. Aparin, I.O., Farzan, V.M., Veselova, O.A., Chistov, A.A., Podkolzin, A.T., Ustinov, A.V., Shipulin, G.A., Formanovsky, A.A., Korshun, V.A., and Zatsepin, T.S., Analyst, 2016, vol. 141, pp. 1331-1338.

https://doi.org/10.1039/c5an01767j

11. Natyrov, A.N., Matvienko, I.V., Bayramov, V.M., Alexeev, J.I., Vlasova, N.A., Volkov, E.M., and Kurochkin, V.E., Russ. J. Bioorg. Chem., 2018, vol. 44, pp. 562-571.

https://doi.org/10.1134/S1068162018040131
12. Matvienko, I.V., Bayramov, V.M., Parygina, N.A., Kurochkin, V.E., and Alekseev, Y.I., Russ. J. Bioorg. Chem., 2020, vol. 46, pp. 349-359. https://doi.org/10.1134/S1068162020030127

13. Ryazantsev, D.Y., Tsybulsky, D.A., Prokhorenko, I.A., Kvach, M.V., Martynenko, Y.V., Philipchenko, P.M., Shmanai, V.V., Korshun, V.A., and Zavriev, S.K., Anal. Bioanal. Chem., 2012, vol. 404, pp. 59-68. https://doi.org/10.1007/s00216-012-6114-4

14. Ryazantsev, D.Y., Kvach, M.V., Tsybulsky, D.A., Prokhorenko, I.A., Stepanova, I.A., Martynenko, Y.V., Gontarev, S.V., Shmanai, V.V., Zavriev, S.K., and Korshun, V.A., Analyst, 2014, vol. 139, pp. 2867-2872. https://doi.org/10.1039/c4an00081a

15. Tsybulsky, D.A., Kvach, M.V., Ryazantsev, D.Y., Aparin, I.O., Stakheev, A.A., Prokhorenko, I.A., Martynenko, Y.V., Gontarev, S.V., Formanovsky, A.A., Zatsepin, T.S., Shmanai, V.V., Korshun, V.A., and Zavriev, S.K., Mol. Cell. Probes, 2016, vol. 30, pp. 285290. https://doi.org/10.1016/j.mcp.2016.10.003

16. Haralambidis, J., Angus, K., Pownall, S., Duncan, L., Chai, M., and Tregear, G.W., Nucleic Acids Res., 1990, vol. 18 , pp. 501-505.

https://doi.org/10.1093/nar/18.3.501

17. Martin, V.V., Alferiev, I.S., and Weis, A.L., Tetrahedron Lett., 1999, vol. 40, pp. 223-226. https://doi.org/10.1016/S0040-4039(98)02280-1

18. Martynenko-Makaev, Yu.V., Brylev, V.A., and Udodova, V.V., Ves. Nats. Akad. Navuk Belarusi, Ser. Khim. Navuk, 2017, vol. 3, pp. 72-78.

19. Povedailo, V.A., Lysenko, I.L., Tikhomirov, S.A., Yakovlev, D.L., Tsybulsky, D.A., Kruhlik, A.S., Fan, F., Martynenko-Makaev, Y.V., Sharko, O.L., Duong, P.V., Minh, P.H., and Shmanai, V.V., J. Fluoresc., 2020, vol. 30, pp. 629-635. https://doi.org/10.1007/s10895-020-02535-w

20. Washio, I., Shibasaki, Y., and Ueda, M., Org. Lett., 2007, vol. 9, pp. 1363-1366. https://doi.org/10.1021/o10702425

21. Knör, S., Modlinger, A., Poethko, T., Schottelius, M. Wester, H.-J., and Kessler, H., Chem.-Eur. J., 2007, vol. 13, pp. 6082-6090. https://doi.org/10.1002/chem.200700231

22. Kvach, M.V., Tsybulsky, D.A., Ustinov, A.V., Stepanova, I.A., Bondarev, S.L., Gontarev, S.V., Korshun, V.A., and Shmanai, V.V., Bioconjugate Chem., 2007, vol. 18, pp. 1691-1696. https://doi.org/10.1021/bc7001874

23. Wang, Q., Chan, T.R., Hilgraf, R., Fokin, V.V., Sharpless, K.B., and Finn, M.G., J. Am. Chem. Soc., 2003, vol. 125 , pp. $3192-3193$. https://doi.org/10.1021/ja021381e

24. Farzan, V.M., Ulashchik, E.A., Martynenko-Makaev, Y.V., Kvach, M.V., Aparin, I.O., Brylev, V.A., Prikazchikova, T.A., Maklakova, S.Y., Majouga, A.G., Ustinov, A.V., Shipulin, G.A., Shmanai, V.V., Korshun, V.A., and Zatsepin, T.S., Bioconjugate Chem., 2017, vol. 28, pp. 2599-2607.

https://doi.org/10.1021/acs.bioconjchem.7b00462 